\title{
UPAYA MENINGKATKAN MOTIVASI DAN HASIL BELAJAR MATEMATIKA MELALUI PENERAPAN TUTOR SEBAYA DENGAN STRATEGI PEMBELAJARAN MODEL ARISAN
}

\author{
NUR KHOIROTIN \\ Madrasah Tsanawiyah Negeri 1 Madiun Jawa Timur \\ Email : nurkhoirotin522@gmail.com
}

\begin{abstract}
ABSTRAK
Penelitihan ini bertujuan untuk meningkatkan motivasi dan hasil belajar matematika pada pokok bahasan pola bilangan melalui penerapan tutor sebaya dengan strategi pembelajaran model arisan. Jenis penelitian ini adalah penelitian tindakan kelas. Subyek penelitian ini adalah guru dan siswa kelas VIIIB Madrasah Tsanawiyah Negeri 1 Madiun yang berjumlah 30 siswa. Metode pengumpulan data dilakukan melalui observasi dan tes. Teknis analisis data yang digunakan dengan cara pengamatan dan tes hasil belajar. Hasil penelitian menunjukkan adanya peningkatan motivasi dan hasil belajar matematika. Penemuan penelitian menunjukkan: motivasi terhadap pembelajaran matematika sebelum tindakan sebesar $52,67 \%$ meningkat menjadi $85,83 \%$ pada siklus II. Peningkatan motivasi belajar matematika diperkuat dengan hasil belajar yaitu sebelum tindakan rata-rata nilai kelas sebesar 51,66 dan pada siklus II rata-rata nilainya meningkat menjadi 85,67 . Kesimpulan penelitian ini adalah penerapan tutor sebaya dengan strategi pembelajaran model arisan dapat meningkatkan motivasi dan hasil belajar matematika pada pokok bahasan pola bilangan siswa kelas VIIIB Madrasah Tsanawiyah Negeri 1 Madiun.
\end{abstract}

Kata Kunci: Motivasi dan Hasil belajar, Tutor Sebaya, Model Arisan

\section{PENDAHULUAN}

Prestasi belajar siswa di kelas sangat dipengaruhi oleh proses pembelajaran yang dilakukan oleh guru, apabila pembelajaran kepada siswa mengacu pada siswa mencapai kompetensi tertentu. Kompetensi adalah kemampuan yang dapat dilakukan siswa yang mencakup pengetahuan, keterampilan, dan perilaku (Depdiknas, 2003:2). Oleh karena itu cara guru mengajar di kelas sangat berdampak terhadap perolehan belajar siswa. Apabila penyajian suatu materi menarik, siswa tentu akan lebih senang dan termotivasi untuk belajar. Metode pembelajaran yang diterapkan guru sangat bermakna bagi siswa.

Salah satu cara untuk meningkatkan hasil belajar siswa yaitu penerapan tutor sebaya dengan strategi pembelajaran model arisan (nama yang diberikan peneliti). Siswa yang memiliki kemampuan rendah membentuk sebuah kelompok belajar. Dalam kelompok belajar ini, siswa yang nilainya baik atau pandai ditunjuk sebagai tutor sebaya. Tutor sebaya adalah siswa yang pandai yang ditunjuk atau ditugaskan membantu temannya yang mengalami kesulitan belajar dan untuk menyelesaikan masalah (Conny, 1992:70). Menurut Silberman (2010:183) tutor sebaya adalah strategi yang berfungsi untuk meningkatkan pengajaran sesama yang memberikan seluruh tanggung jawab mengajar sesama peserta dalam kelompok.

Model pembelajaran ini menggunakan prinsip inkuiri dan pemantapan konsep. Siswa memperoleh informasi dari guru, kemudian dengan soal-soal yang diberikan siswa mengerjakan untuk mencari jawaban berdasarkan konsep yang telah diberikan bersama kelompoknya.

Langkah-langkah pembelajaran model arisan adalah sebagai berikut : (1) guru menyiapkan soal-soal dan kertas kerja yang akan diberikan pada masing-masing kelompok, (2) pemilihan siswa ahli (tutor sebaya) yang dilakukan oleh seluruh siswa dalam kelas yang selanjutnya dijadikan sebagai ketua kelompok, (3) pembentukan ketua kelompok secara acak dengan cara berhitung satu sampai sejumlah kelompok dengan dibimbing guru. Siswa dengan nomor yang sama masuk dalam satu kelompok, (4) siswa ahli yang telah terpilih, masingmasing mengambil undian yang sudah disediakan dan masuk dalam kelompok sesuai dengan nomor undian yang mereka dapatkan, (5) masing-masing kelompok menuliskan nama tutor 
dan nama-nama anggota kelompok dimulai nomor satu nama dan seterusnya sebagai dasar pengundian dalam melakukan presentasi, (6) guru menjelaskan aturan main yang akan dilaksanakan, (7) dengan waktu yang telah ditentukan, guru memberikan 3 soal kepada masing-masing kelompok untuk didiskusikan dan menuliskan hasilnya pada kertas kerja yang diberikan (ketiga soal yang diberikan pada tiap kelompok sama), (8) bila waktu yang telah ditentukan pada point 7 habis, selanjutnya dilakukan undian untuk menentukan kelompok yang akan melakukan presentasi lebih dahulu. Anggota kelompok yang akan presentasi dan nomor soal yang akan dipresentasikan juga dilakukan melalui undian (model arisan), (9) presentasi dilakukan di papan yang telah disediakan dan tidak diperkenankan membawa catatan apapun kecuali soal yang hasilnya akan dipresentasikan, (10) dengan cara yang sama seperti point 8 dilanjutkan presentasi untuk soa-soal yang lain sampai semua soal dipresentasikan, (11) guru menilai presentasi tiap-tiap kelompok dan mengoreksi hasil pekerjaan masing-masing kelompok, (12) evaluasi.

Belajar matematika tidak hanya berhubungan dengan bilangan-bilangan serta operasioperasi, tetapi belajar matematika juga berkenaan dengan ide-ide, struktur-struktur dan hubungan yang diatur secara logis sehingga matematika itu berkaitan dengan konsep-konsep yang abstrak, seperti yang dikemukakan oleh Hudojo (1998:3) mengemukaan bahwa belajar matematika merupakan kegiatan mental yang tinggi, karena matematika berkaitan dengan ideide abstrak yang diberi simbol-simbol yang tersusun secara hirarkis dan penalarannya deduktif. Belajar matematika pada hakekatnya adalah suatu aktifitas mental untuk memahami arti dari struktur-struktur, hubungan-hubungan dan simbol-simbol, kemudian menerapkan konsep-konsep dalam matematika yang dilakukan secara bertahap dan berurutan serta berdasarkan pada pengalaman belajar yang lalu.

Motivasi belajar adalah dorongan internal dan eksternal pada siswa yang sedang belajar untuk mengadakan tingkah laku, pada umumnya dengan beberapa indikator atau unsur-unsur yang mendukung indikator-indikator tersebut, antara lain adanya hasrat dan keinginan berhasil, dorongan dan kebutuhan dalam belajar, harapan dan cita-cita masa depan, penghargaan dalam belajar, dan lingkungan belajar yang kondusif (Hamzah, 2011:32)

Hasil belajar siswa pada hakekatnya adalah perubahan tingkah laku setelah mengalami aktivitas belajar (Oemar, 1991:5). Perubahan sebagai hasil proses dapat ditunjukkan dalam berbagai bentuk seperti perubahan pengertian, pemahaman, keterampilan, kecakapan, serta perubahan aspek-aspek lain yang ada pada individu yang belajar. Tingkah laku sebagai pengertian yang luas mencakup bidang kognitif, afektif, dan psikomotorik. Dalam ranah kognitif, hasil belajar merupakan perubahan pengetahuan, kemampuan, dan kemahiran intektual. Hasil belajar dalam ranah afektif merupakan perubahan untuk menerima dan perubahan terhadap pola hidup. Hasil belajar dalam ranah psikomotorik adalah perubahan dalam kemampuan fisik seperti keterampilan motorik, manipulasi objek, dan koordinasi syaraf.

Hasil penelitihan yang relevan dengan variabel hasil belajar matematika dan penerapan tutor sebaya: (a) Widiayanto (Universitas Sebelas Maret, 2019) "Penerapan Metode Tutor Sebaya untuk Meningkatkan Hasil Belajar Siswa pada Materi Rumus dan Fungsi Microsoft Excel" hasil penelitiannya menunjukkan bahwa penggunaan metode tutor sebaya dapat meningkatkan hasil belajar informatika pada materi mengenal rumus dan fungsi microsoft excel kelas VIIF SMPN 6 Kebumen Tahun Pelajaran 2019/2020. (b) Pantjana (SMK Negeri 1 Magelang, 2020) "Pembelajaran Tutor Sebaya Berbantuan Lingsat Dalam Meningkatkan Motivasi dan Hasil Belajar Matematika" hasil penelitiannya menunjukkan bahwa pembelajaran tutor sebaya berbantuan Lingsat dapat meningkatkan motivasi dan hasil belajar matematika. (c) Winarti (SMA Negeri 1 Turi, 2020) "Penerapan Metode Tutor Sebaya Untuk Meningkatkan Motivasi dan Hasil Belajar Kimia" hasil penelitiannya menunjukkan bahwa pembelajaran dengan menerapkan metode tutor sebaya dapat meningkatkan motivasi dan hasil belajar siswa. 
Tujuan penelitian ini untuk meningkatkan motivasi dan hasil belajar matematika pada pokok bahasan pola bilangan melalui penerapan tutor sebaya dengan strategi pembelajaran model arisan siswa kelas VIIIB Madrasah Tsanawiyah Negeri 1 Madiun Tahun Pelajaran $2019 / 2020$.

\section{METODE PENELITIAN}

Jenis data yang digunakan dalam penelitihan ini adalah data kualitatif. Data kualitatif diperoleh dari observasi yang dilakukan kepada siswa untuk mengamati proses pembelajaran pada kedua siklus. Subyek penelitian adalah siswa kelas VIIIB yang berjumlah 30 siswa terdiri dari laki-laki 15 siswa dan perempuan 15 siswa. Subyek pelaksana tindakan kelas adalah guru Nur Khoirotin. Obyek penelitian adalah motivasi dan hasil belajar matematika, tutor sebaya, strategi pembelajaran model arisan. Adapun teknik pengumpulan data melalui: (1) observasi, (2) tes. Sedangkan metode analisis datanya melalui: (1) pengamatan (2) tes hasil belajar

\section{HASIL DAN PEMBAHASAN}

\section{Hasil}

Berdasarkan hasil pelaksanaan tindakan kelas siklus I dan siklus II tentang penerapan tutor sebaya dengan strategi pembelajaran model arisan pada pembelajaran matematika kelas VIIIB Madrasah Tsanawiyah Negeri 1 Madiun, maka hasil data motivasi belajar dengan pencapaian $\geq 80 \%$ dapat kebenarannya sebagai berikut:

Penerapan tutor sebaya dengan strategi pembelajaran model arisan dapat meningkatkan motivasi belajar matematika siswa kelas VIIIB Madrasah Tsanawiyah Negeri 1 Madiun Tahun Pelajaran 2019/2020. Hal ini dapat dibuktikan dengan peningkatan prosentase dalam tahapan sebelum pembelajaran, siklus I, dan siklus II sebagai berikut:

Tabel 1. Prosentase motivasi belajar matematika

\begin{tabular}{|c|l|c|c|c|c|}
\hline No & \multicolumn{1}{|c|}{ Nama siswa } & $\begin{array}{c}\text { Sebelum } \\
\text { tindakan }\end{array}$ & $\begin{array}{c}\text { Siklus } \\
\text { I }\end{array}$ & $\begin{array}{c}\text { Siklus } \\
\text { II }\end{array}$ & Ket. \\
\hline 1 & AAN DWI SETYA AJI & 55 & 65 & 85 & Baik \\
\hline 2 & AGUNG SATRIO WIBOWO & 55 & 60 & 85 & Baik \\
\hline 3 & ALEX CANDRA SAIFULLAH & 40 & 65 & 80 & Baik \\
\hline 4 & ANDINI RIFDA MAULANA & 30 & 60 & 80 & Baik \\
\hline 5 & ASSHIFA PUTRI TARUMI & 45 & 65 & 80 & Baik \\
\hline 6 & DAVIN ARDIANSYAH & 50 & 75 & 85 & Baik \\
\hline 7 & DEWI PRAMESWARI & 60 & 65 & 95 & Baik \\
\hline 8 & DIKA ALFAN PRASETYO & 65 & 80 & 95 & Baik \\
\hline 9 & DZIKRINA AURA S. & 60 & 70 & 80 & Baik \\
\hline 10 & FABILLAL REIHAN MAHESA & 50 & 65 & 80 & Baik \\
\hline 11 & FANIYA DIWAR PARAMITA & 70 & 80 & 90 & Baik \\
\hline 12 & FAUZIAH NOVITARIFANI A. & 45 & 60 & 85 & Baik \\
\hline 13 & FIRHAN RANGGA M. & 55 & 70 & 90 & Baik \\
\hline 14 & GIZA AYU AIDIL FITRI & 60 & 65 & 85 & Baik \\
\hline 15 & KHANSA FEBRINA R. & 50 & 65 & 80 & Baik \\
\hline 16 & MAULANA FAIZ AINUL A. & 65 & 75 & 85 & Baik \\
\hline 17 & MOHAMAD NURHUDA & 45 & 65 & 80 & Baik \\
\hline 18 & MUALIFA SEPTI N. & 40 & 60 & 75 & Baik \\
\hline 19 & MUHAMMAD NATAIJUL A. & 50 & 70 & 80 & Baik \\
\hline 20 & MUNTIA LAILATUL F. & 40 & 70 & 80 & Baik \\
\hline 21 & RIDWAN DWY NURHABIB & 45 & 70 & 85 & Baik \\
\hline 22 & RIFAUL KHOYRUDDIN A. & 55 & 75 & 90 & Baik \\
\hline
\end{tabular}


PAEDAGOGY : Jurnal IImu Pendidikan dan Psikologi

Vol. 1 No. 1 Juni 2021 e-ISSN : 2797-3344 P-ISSN : 2797-3336

\begin{tabular}{|c|l|c|c|c|c|}
\hline 23 & RYAN ARDIANSYAH & 60 & 75 & 90 & Baik \\
\hline 24 & SINTA NUR INDAH SARI & 45 & 70 & 85 & Baik \\
\hline 25 & SITI NUR ALFIAH & 45 & 70 & 95 & Baik \\
\hline 26 & WAHYU NAZRIL ILHAM & 65 & 75 & 90 & Baik \\
\hline 27 & WARDATUL ELSA BILBINA & 70 & 80 & 85 & Baik \\
\hline 28 & WISNU KRISNA SAPUTRA & 45 & 65 & 95 & Baik \\
\hline 29 & YESHA ATALIA & 70 & 75 & 95 & Baik \\
\hline 30 & YULI ANTI & 50 & 65 & 90 & Baik \\
\hline & Jumlah & 1580 & 2070 & 2575 & \\
\hline & Skor maksimal & 3000 & 3000 & 3000 & \\
\hline & Prosentase $(\%)$ & 52,67 & 69,00 & 85,83 & \\
\hline
\end{tabular}

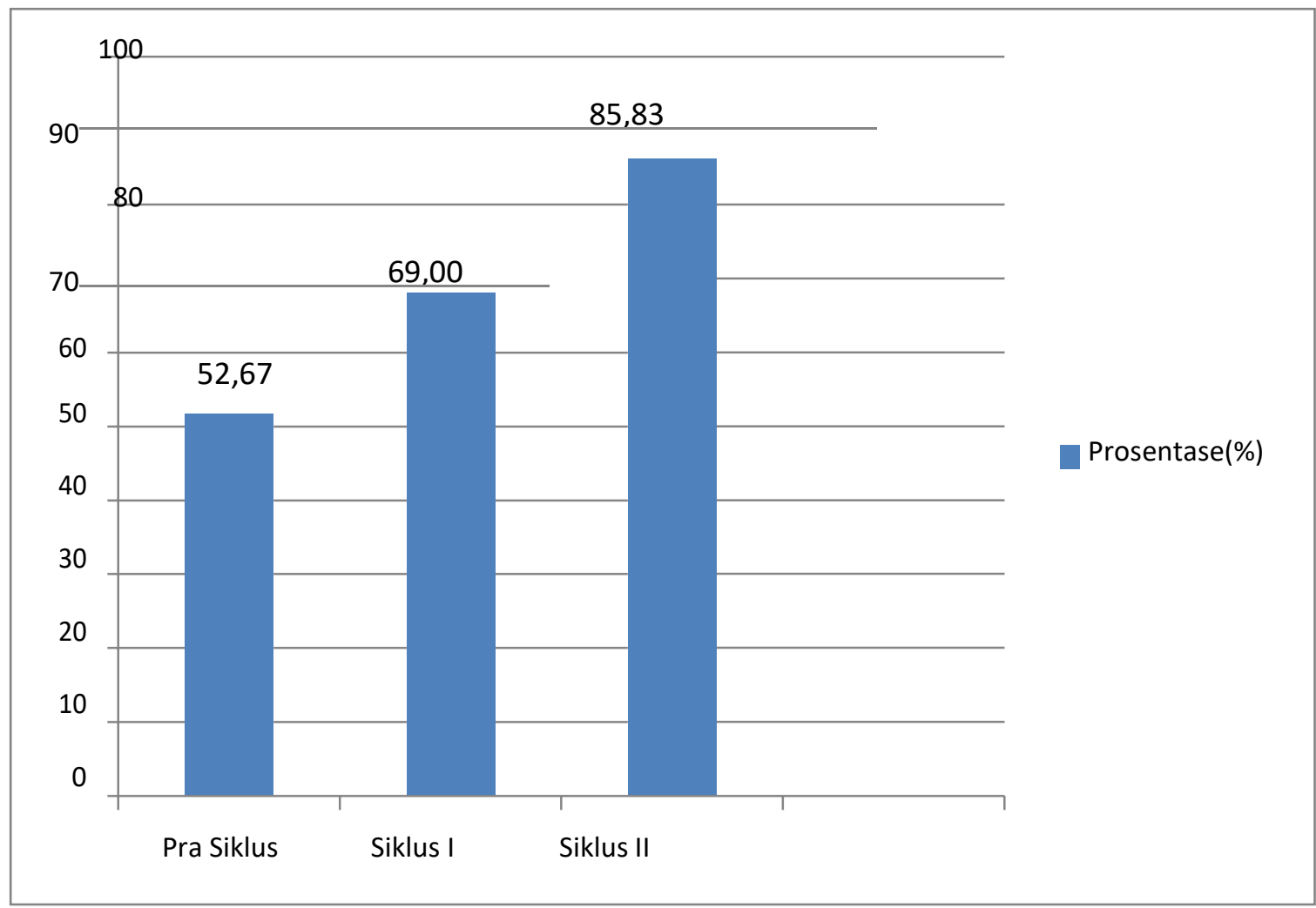

\section{Gambar 1. Grafik perbandingan motivasi belajar}

Penerapan tutor sebaya dengan strategi pembelajaran model arisan dapat meningkatkan hasil belajar matematika siswa kelas VIIIB Madrasah Tsanawiyah Negeri 1 Madiun Tahun Pelajaran 2019/2020. Hal ini dapat dibuktikan dengan peningkatan prosentase ketuntasan dalam hasil belajar dalam tahapan sebelum pembelajaran, siklus I, dan siklus II sebagai berikut:

Tabel 2. NilaiKetuntasan hasil belajar matematika

\begin{tabular}{|c|l|c|c|c|c|}
\hline No & \multicolumn{1}{|c|}{ Nama Siswa } & $\begin{array}{c}\text { Sebelum } \\
\text { tindakan }\end{array}$ & Siklus I & $\begin{array}{c}\text { Siklus } \\
\text { II }\end{array}$ & Ket. \\
\hline 1 & AAN DWI SETYA AJI & 50 & 85 & 95 & Tuntas \\
\hline 2 & AGUNG SATRIO WIBOWO & 45 & 60 & 85 & Tuntas \\
\hline 3 & ALEX CANDRA SAIFULLAH & 40 & 55 & 80 & Tuntas \\
\hline 4 & ANDINI RIFDA MAULANA & 45 & 60 & 80 & Tuntas \\
\hline 5 & ASSHIFA PUTRI TARUMI & 50 & 65 & 85 & Tuntas \\
\hline 6 & DAVIN ARDIANSYAH & 45 & 75 & 85 & Tuntas \\
\hline 7 & DEWI PRAMESWARI & 50 & 80 & 95 & Tuntas \\
\hline 8 & DIKA ALFAN PRASETYO & 55 & 75 & 85 & Tuntas \\
\hline
\end{tabular}


PAEDAGOGY : Jurnal IImu Pendidikan dan Psikologi

Vol. 1 No. 1 Juni 2021 e-ISSN : 2797-3344 P-ISSN : 2797-3336

\begin{tabular}{|c|l|c|c|c|c|}
\hline 9 & DZIKRINA AURA S. & 50 & 75 & 85 & Tuntas \\
\hline 10 & FABILLAL REIHAN MAHESA & 55 & 65 & 85 & Tuntas \\
\hline 11 & FANIYA DIWAR PARAMITA & 50 & 65 & 85 & Tuntas \\
\hline 12 & FAUZIAH NOVITARIFANI A. & 50 & 50 & 80 & Tuntas \\
\hline 13 & FIRHAN RANGGA M. & 60 & 60 & 80 & Tuntas \\
\hline 14 & GIZA AYU AIDIL FITRI & 75 & 85 & 95 & Tuntas \\
\hline 15 & KHANSA FEBRINA R. & 75 & 85 & 95 & Tuntas \\
\hline 16 & MAULANA FAIZ AINUL A. & 30 & 55 & 80 & Tuntas \\
\hline 17 & MOHAMAD NURHUDA & 35 & 60 & 85 & Tuntas \\
\hline 18 & MUALIFA SEPTI N. & 40 & 60 & 85 & Tuntas \\
\hline 19 & MUHAMMAD NATAIJUL A. & 55 & 75 & 90 & Tuntas \\
\hline 20 & MUNTIA LAILATUL F. & 75 & 80 & 95 & Tuntas \\
\hline 21 & RIDWAN DWY NURHABIB & 30 & 55 & 80 & Tuntas \\
\hline 22 & RIFAUL KHOYRUDDIN A. & 75 & 80 & 90 & Tuntas \\
\hline 23 & RYAN ARDIANSYAH & 55 & 65 & 85 & Tuntas \\
\hline 24 & SINTA NUR INDAH SARI & 55 & 65 & 80 & Tuntas \\
\hline 25 & SITI NUR ALFIAH & 60 & 85 & 90 & Tuntas \\
\hline 26 & WAHYU NAZRIL ILHAM & 40 & 60 & 85 & Tuntas \\
\hline 27 & WARDATUL ELSA BILBINA & 45 & 75 & 85 & Tuntas \\
\hline 28 & WISNU KRISNA SAPUTRA & 35 & 60 & 75 & Tuntas \\
\hline 29 & YESHA ATALIA & 60 & 75 & 80 & Tuntas \\
\hline 30 & YULI ANTI & 75 & 75 & 90 & Tuntas \\
\hline & Jumlah & 51,66 & 68,83 & 85,67 & \\
\hline & Rata-rata & & & & \\
\hline
\end{tabular}

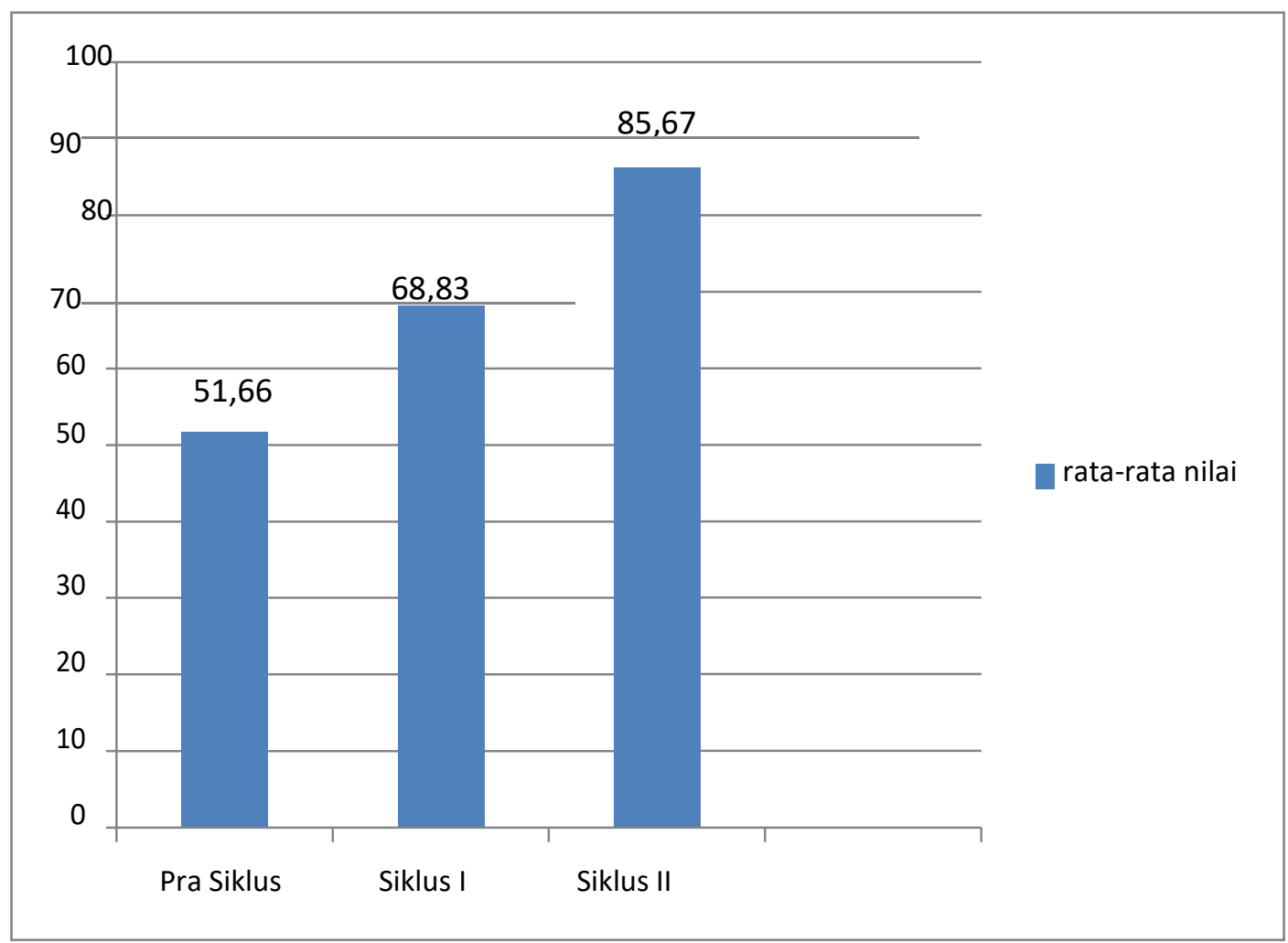

Gambar 2. Grafik Perbandingan hasil belajar matematika 


\section{Pembahasan}

Hasil yang diperoleh dari pratindakan ke siklus I pada motivasi belajar siswa sudah ada peningkatan prosentase dari 52,67\% menjadi 69,00\%. Hal ini berarti sudah ada peningkatan motivasi belajar siswa pada materi pola bilangan melalui penerapan tutor sebaya dengan strategi pembelajaran model arisan walaupun belum sempurna. Pada hasil siklus II prosentase menjadi $85,83 \%$, ini menunjukkan bahwa secara klasikal, siswa memiliki motivasi yang sangat baik terhadap belajar matematika siswa. penerapan tutor sebaya dengan strategi pembelajaran model arisan. Hal ini juga sesuai dengan hasil penelitian Kurniawan dan Jaedun (2018) bahwa penerapan metode tutor sebaya dapat meningkatkan motivasi dan hasil belajar siswa pada mata pelajaran estimasi biaya konstruksi dan properti SMKN 2 Wonosari.

Berdasarkan tabel ketuntasan hasil belajar matematika, sebelum tindakan ada 5 siswa dari 30 siswa yang belum tuntas dengan nilai rata-rata 51,66. Hal ini berarti hasil belajar siswa sangatlah rendah. Pada siklus I nilai rata-rata siswa meningkat menjadi 68,83. Berarti pada siklus I sudah ada peningkatan hasil belajar siswa walaupun masih sedikit artinya ada pengaruh penerapan model pembelajaran pada hasil belajar siswa. Pada siklus II meningkat menjadi $85,67 \%$, ini berarti secara klasikal sudah mencapai ketuntasan belajar $(\geq 80 \%)$. Hal ini sejalan pula dengan temuan-temuan penelitian lain seperti yang dilakukan oleh (Abrianto, 2019) dan (Listari et al., 2020) yang pada dasarnya menyatakan bahwa penerapan tutor sebaya dapat berpengaruh terhadap hasil belajar siswa. Dengan demikian dapat dikatakan penerapan tutor sebaya dengan strategi pembelajaran model arisan dapat meningkatkan motivasi dan hasil belajar siswa. Penerapan Tutor sebaya dengan strategi pembelajaran model arisan sangat membantu guru meningkatkan kualitas pembelajaran di kelas dalam mempelajari materi pola bilangan.

\section{KESIMPULAN}

Berdasarkan rangkaian kegiatan penelitihan yang dilakukan sebelum tindakan hingga siklus II menunjukkan adanya peningkatan perubahan yaitu terjadi peningkatan motivasi dan belajar matematika siswa melalui penerapan tutor sebaya dengan strategi pembelajaran model arisan pada pola bilangan kelas VIIIB Madrasah Tsanawiyah Negeri 1 Madiun Tahun Pelajaran 2019/2020. Penelitian ini juga mampu mengubah pola mengajar yang dilakukan guru, yaitu guru yang semula hanya menggunakan metode yang monoton menjadi metode yang menyenangkan, sehingga dalam pembelajaran siswa menjadi semangat dan termotivasi dalam pembelajaran matematika. Dengan adanya motivasi belajar matematika maka belajar siswa akan meningkat.

Berdasarkan hasil penelitian tindakan kelas yang dilakukan peneliti maka dapat diambil kesimpulan sebagai berikut: (1) Pembelajaran matematika melalui penerapan tutor sebaya dengan strategi pembelajaran model arisan dapat meningkatkan motivasi belajar matematika siswa dalam setiap siklus. (2) Motivasi siswa saat pembelajaran berlangsung meningkat mulai dari sebelum tindakan 52,67\%, siklus I 69,00\% dan siklus II $85,83 \%$. (3) Pembelajaran matematika dengan tutor sebaya dengan strategi pembelajaran model arisan dapat meningkatkan hasil belajar matematika siswa yaitu sebelum tindakan siswa yang mencapai KKM (tuntas belajar) adalah 5 siswa (16,67\%), pada siklus I siswa yang tuntas 14 siswa (46,67\%), dan pada siklus II siswa yang tuntas 30 siswa (100\%).

\section{DAFTAR PUSTAKA}

Abrianto, R. O. (2019). Penerapan Metode Tutor Sebaya Untuk Meningkatkan Hasil Belajar dan Motivasi Belajar Siswa Kelas XI MIPA 4 SMA Negeri 1 Ambarawa. Ejournal.uksw.edu/satyawidya/article/download/2438/1190.

Conny, Semiawan. (1992). Pendekatan Ketrampilan Proses. Jakarta: Grasindo.

Departemen Pendidikan Nasional. (2003). Kurikulum 2004. Jakarta: Depdinas.

Hamzah, B. Uno. (2011). Teori Motivasi dan Pengukurannya. Jakarta: Bumi Aksara.

Hudojo, Herman. (1998). Mengajar Belajar Matematika. Bandung: Yrama Widya.

Kurniawan, I. R., Jaedun, A. (2018). Penerapan Metode Tutor Sebaya Untuk Meningkatkan 
Motivasi dan Hasil Belajar Siswa Pada Mata Pelajaran Estimasi Biaya Konstruksi dan Properti SMKN 2 Wonosari. Journal.student.uny.ac.id/ojs/ojs/index/2018.

Listari, W. A., Mangesa, T. R., Muliadi. (2020). Penerapan Tutor Sebaya Dalam Implementasi Strategi CIRC Berbasis Aktive Learning Untuk Meningkatkan Hasil Belajar Siswa Pada Mata Pelajaran Sistem Komputer di SMKN 5 Makassar. Ojs.unm.ac.id/mediaTIK/article/download/15174/8882.

Oemar, Hamalik. (1991). Kurikulum dan Pembelajaran. Jakarta: PT. Bumi Aksara.

Pantjana, Harda. (2020). Pembelajaran Tutor Sebaya Berbantuan Lingsat dalam Meningkatkan Motivasi dan Hasil Belajar Matematika. Indonesia Journal of education and Learning Vol.4/No.1/Oktober/2020.

Silberman, Mel. (2010). Active Learning: 101 Strategi Pembelajaran Aktif. Yogyakarta: Pustaka Insan Madani

Widiayanto, Hari. (2019). Penerapan Metode Tutor Sebaya Untuk Meningkatkan Hasil Belajar Siswa pada Materi Rumus dan Fungsi Microsoft Excel. Jurnal Riset Pedagogig 3(2)(2019) 156-1.

Winarti, Sri. (2020). Penerapan Metode Tutor Sebaya Untuk Meningkatkan Motivasi dan Hasil Belajar Kimia. Jurnal dikpora. jogyaprov. go.id/index.php/jurnalideguru. 